
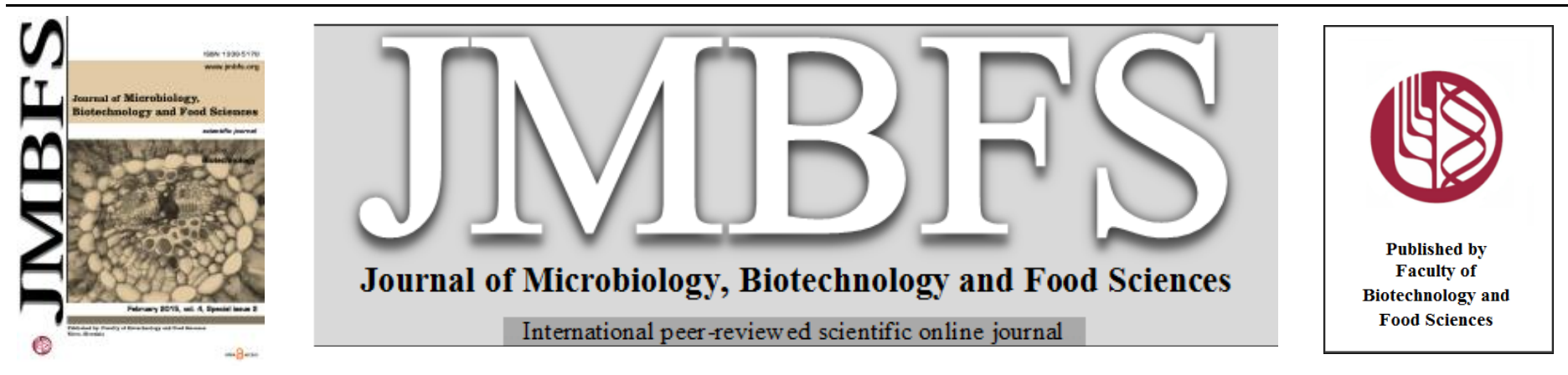

\title{
ASSESSMENT OF RAPD POLYMORPHISM IN RYE (SECALE CEREALE L.) GENOTYPES
}

\section{Lenka Petrovičová* ${ }^{1}$, Zdenka Gálová ${ }^{1}$, Želmíra Balážová ${ }^{1}$, Martin Vivodik ${ }^{1}$, Magdalena Wójcik-Jagła ${ }^{2}$, Marcin Rapacz $^{2}$}

Address(es): Ing. Lenka Petrovičová

${ }^{1}$ Slovak University of Agriculture, Faculty of Biotechnology and Food Sciences, Department of Biochemistry and Biotechnology, 94976 Nitra, Slovak Republic;

${ }^{2}$ University of Agriculture in Krakow, Faculty of Agriculture and Economics, Department of Plant Physiology, 31-120 Krakow, Poland.

*Corresponding author: petrovicovalenka22@gmail.com

doi: 10.15414/jmbfs.2015.4.special2.94-97

\section{ARTICLE INFO}

Received 19. 11. 2014

Revised 10. 12. 2014

Accepted 24. 12. 2014

Published 2. 2. 2015

Regular article

open 2 access

\section{ABSTRACT}

The results of genetic analysis of 38 rye taxa (Secale cereale L.) represented by agricultural varieties originating from Central Europe and the Union of Soviet Socialist Republics (SUN) are presented. The genetic diversity of rye cultivars by 5 RAPD markers was evaluated. Five primers gave 42 polymorphic fragments $(99.52 \%)$ with an average of 8.4 bands per primer. The most polymorphic primer was RLZ12, where 10 polymorphic amplification products were detected. Overleaf the lowest polymorphic primer was RLZ5 with 7 polymorphic products. Genetic polymorphism was characterized based on diversity index (DI), probability of identity (PI) and polymorphic information content (PIC). The dendrogram of genetic similarity was constructed, based on the Jaccard's coefficient. In dendrogram three clusters were differentiated. The first cluster contained genotypes from Czechoslovakia, Poland and Czech Republic. The second cluster contained cultivars coming from Union of Soviet Socialist Republics and Hungary. In the next cluster Poland, Czech Republic and Czechoslovakia genotypes were situated. Two genotypes Bosmo and Wibro have not been distinguished. For better distinction of the analysed rye genotypes, it is necessary to use a higher number of RAPD markers. In this experiment, RAPD proved to be a rapid, reliable and practicable method for revealing of polymorphism in the rye cultivars.

Keywords: Rye (Secale cereale L.), polymorphism, RAPD, dendrogram

\section{INTRODUCTION}

Rye (Secale cereale $\mathrm{L}$.) is a diploid $(2 \mathrm{n}=2 \mathrm{x}=14)$ annual, cross-pollinated cereal with an effective gametophytic self-incompatibility system. Similar to many crops of the old World, S. cereale evolved of the Near East. Main regions of diversity are Turkey, Libanon, Syria, Iran, Iraq, and Afghanistan. Rye was, however, never cultivated as a crop there but grew and still grows as a weed within the stands of barley and wheat (Carena, 2009). On a global scale rye (Secale cereale L.) is a minor crop, its production being about $5 \%$ that of wheat or rice. However, in northern European countries with extreme climatic and poor soil conditions, rye may occupy up to $30 \%$ of the acreage (Altpeter and Konzun, 2007). The main advantages of rye over other winter cereals are its excellent tolerance to low temperatures and the ability to realize relatively high grain yields under environmental conditions in which other crops perform poorly. Rye is also known to have the lowest requirements for chemical treatments like fertilizers or pesticides, which makes it an ecologically and economically sound crop for specific regions (Konzun et al., 2001).

Since 1990, random amplified polymorphic DNA (RAPD) markers have been successfully applied for identification of DNA polymorphism in various plant species (Williams et al., 1990). They are often used for screening of a wide range of genetic stocks in order to find linkage with traits of agronomic significance (Masojć et al., 2001).

Suitability of RAPD markers for the construction of genetic maps, fingerprinting and phylogenetic studies has been proved by many authors (Yang and Quiros, 1995; Nilsson et al., 1997; Divaret et al., 1999). In cereal crops such as wheat (Saleh, 2012; Bibi et al., 2012), peach (Bakht et al., 2013), barley (Bakht et al., 2011), the technique has been applied to identifying cultivars and revealing phylogenetic relationships among them. In the case of rye, there are a few papers (Iqbal and Rayburn, 1994; Matos et al., 2001; Persson et al., 2002; Petrovičová et al., 2014) that have reported the application of the RAPD marker technique to rye molecular identification, and the technique was proved to be effective for characterizing the genetic background of rye (Ma et al., 2004). The aim of our study was to detect genetic variability among the set of 38 rye genotypes using 5 RAPD primers.

\section{MATERIAL AND METHODS}

\section{Plant Material}

Thirty eight rye (Secale cereale L.) genotypes were used in the present study. Seeds of rye were obtained from the Gene Bank of the Slovak Republic of the Plant Production Research Center in Piešt'any and Gene Bank of the Czech Republic of the Crop Research Institute in Prague (Tab 1).

\section{DNA Isolation}

Genomic DNA of rye cultivars was extracted from 14 days leaves with GeneJET Plant Genomic DNA Purification Mini Kit (Thermo Scietific, Gdańsk, Poland) according to the manufacturer's instructions. DNA concentrations were estimated by UV-Vis spectrophotometer Q5000, Quawell.

\section{Polymerase Chain Reaction (PCR) and Gel Electrophoresis}

RAPD analyses were performed using five random 10mer arbitrary primers (Tab 2) obtained from Genomed, Warsaw, Poland. Amplification DNA was conducted in $25 \mu \mathrm{l}$ reaction volume containing the following reagents: $10.25 \mu 1$ deionized water, 12.5 $\mu$ l Master Mix (2x Master Mix, A\&A Biotechnology, Gdynia, Poland), $1.25 \mu \mathrm{l}$ of genomic DNA, $1 \mu \mathrm{l}$ of primer. PCR amplifications were performed on a labcycler (Sencoquest, Göttingen, Germany) following amplification profile: An initial denaturation step at $94^{\circ} \mathrm{C}$ for $1 \mathrm{~min}$, followed by 10 cycles of amplification $5 \mathrm{~s}$ at $94^{\circ} \mathrm{C}, 30 \mathrm{~s}$ at $37^{\circ} \mathrm{C}$ and $30 \mathrm{~s}$ at $72^{\circ} \mathrm{C}$ and next 35 cycles of $5 \mathrm{~s}$ at $94^{\circ} \mathrm{C}, 30 \mathrm{~s}$ at $37^{\circ} \mathrm{C}$ and $1 \mathrm{~min}$ at $72{ }^{\circ} \mathrm{C}$.

Amplified products were size-fractioned using by electrophoresis in $1 \%$ agarose gels in $1 \mathrm{x}$ TBE buffer at $170 \mathrm{~V}$ for $1.5 \mathrm{~h}$. GeneRulerTM 1kb Plus DNA Ladder (Fermentas, Gdansk, Poland) that gives 15 bands from 75 to $20000 \mathrm{bp}$, was used as standard. The bands were visualized by Midori Green staining (Nippon Genetics Europe GmbH, Düren, Germany) and photographed under UV light using a ChemiDoc ${ }^{\mathrm{TM}}$ MP System (Biorad, Warszawa, Poland).

\section{Data Analysis}

The band intensity and presence of RAPD-PCR products, were analysed by densitometry, using ImageLabTM Software version 4.1 Biorad. Each 
reproducible band was visually scored for the presence (1) or absence (0) for all genotypes. For determination of the genetic relationships between rye genotypes a dendrogram was used. The dendrogram was constructed based on principle of hierarchical cluster analysis using UPGMA (Unweighted Pair Group Method using arithmetic Averages) algorithm on the basis of Jaccard's coefficient in statistical program SPSS.

Frequencies of incidence of all polymorphic alleles were calculated and used for determination of statistical parameters: diversity index (DI) (Weir, 1990), probability of identity (PI) (Paetkau et al., 1995) and polymorphic information content (PIC) (Weber, 1990).
Diversity index (DI) $\quad D I=1-\sum p_{i}^{2}$

Probability of identity (PI) $P I=\sum p_{i}^{4}+\sum_{i=1}^{i=n-1} \sum_{j=i+1}^{n}\left(2 p_{i} p_{j}\right)^{2}$

Polymorphic information content (PIC): $P I C=1-\left(\sum_{i=1}^{n} p_{i}^{2}\right)-\sum_{i=1}^{n-1} \sum_{j=i+1}^{n} 2 p_{i}^{2} \cdot p_{j}^{2}$

$\mathrm{P}_{\mathrm{i}}$ and $\mathrm{p}_{\mathrm{j}}$ are the frequencies of the ith and jth allele in a given genotypes.

Table 1 List of 38 rye cultivars their taxon and country of origin used in this study

\begin{tabular}{|c|c|c|}
\hline Genotype & Taxon & Country of origin \\
\hline Valtické & S. cereale L. subsp. cereale var. cereale & Czechoslovakia \\
\hline Tešovské & S. cereale L. subsp. cereale var. cereale & Czechoslovakia \\
\hline Keřkovské & S. cereale L. subsp. cereale var. cereale & Czechoslovakia \\
\hline Zenit & S. cereale L. subsp. cereale var. cereale & Czechoslovakia \\
\hline Chlumecké & S. cereale L. subsp. cereale var. cereale & Czechoslovakia \\
\hline České & S. cereale L. subsp. cereale var. cereale & Czechoslovakia \\
\hline Albedo & S. cereale L. subsp. cereale var. cereale & Czechoslovakia \\
\hline Židlochovický Panis & S. cereale L. subsp. cereale var. cereale & Czechoslovakia \\
\hline Nalžovské & S. cereale L. subsp. cereale var. cereale & Czechoslovakia \\
\hline Dobrovické & S. cereale L. subsp. cereale var. cereale & Czechoslovakia \\
\hline Vígl'ašské & S. cereale L. subsp. cereale var. cereale & Czechoslovakia \\
\hline Ratbořské & S. cereale L. subsp. cereale var. cereale & Czechoslovakia \\
\hline Laznické & S. cereale L. subsp. cereale var. cereale & Czechoslovakia \\
\hline Breno & S. cereale L. subsp. cereale var. cereale & Czechoslovakia \\
\hline Dobřenické krmné & S. cereale L. var. $h$ & Czechoslovakia \\
\hline Aventino & S. cereale $\mathrm{L}$ & Czech Republic \\
\hline Selgo & S. cereale L. subsp. tetraploidum KOBYL & Czech Republic \\
\hline Warko & S. cereale L. subsp. cereale var. cereale & Poland \\
\hline Dankowskie Zlote & S. cereale L. subsp. cereale var. cereale & Poland \\
\hline Zduno & S. cereale L. subsp. cereale var. cereale & Poland \\
\hline Motto & S. cereale L. subsp. cereale var. cereale & Poland \\
\hline Pancerne & S. cereale L. subsp. cereale var. cereale & Poland \\
\hline Wojcieszyckie & S. cereale L. subsp. cereale var. cereale & Poland \\
\hline Univerzalne & S. cereale L. subsp. cereale var. cereale & Poland \\
\hline Dankowskie Nowe & S. cereale L. subsp. cereale var. cereale & Poland \\
\hline Amilo & S. cereale L. subsp. cereale var. cereale & Poland \\
\hline Wibro & S. cereale L. subsp. cereale & Poland \\
\hline Bosmo & S. cereale $\mathrm{L}$. & Poland \\
\hline Rostockie & S. cereale $\mathrm{L}$. & Poland \\
\hline Hegro & S. cereale $\mathrm{L}$. & Poland \\
\hline Walet & S. cereale $\mathrm{L}$. & Poland \\
\hline Kier & S. cereale L. & Poland \\
\hline Tetra Start & S. cereale L. subsp. tetraploidum KOBYL & SUN \\
\hline Cerkascanka tetra & S. cereale L. subsp. tetraploidum KOBYL & SUN \\
\hline Voschod 1 & S. cereale L. subsp. cereale var. cereale & SUN \\
\hline Golubka & S. cereale L. subsp. cereale var. cereale & SUN \\
\hline Mnogokoloskaja & S. cereale L. subsp. cereale var. cereale & SUN \\
\hline Lovaszpatonai & S. cereale L. subsp. cereale var. cereale & HUN \\
\hline
\end{tabular}

Table 2 List of random primers their sequences and chromosomal location used for RAPD analysis.

\begin{tabular}{lcc}
\hline \hline Primer's name & Sequence & Chromosomal location \\
RLZ1 & 5'AAGCACCGGC3' & 3RS \\
RLZ5 & 5'CGTCGTGGAA3' & 4RL \\
RLZ11 & 5'TCCGCGGTCT3' & 6RS \\
RLZ12 & 5'TGCCGCTAAG3' & 7RL \\
RLZ13 & 5'TCGCGCTGTC3' & 7RL \\
\hline \hline
\end{tabular}

\section{RESULTS AND DISCUSSION}

The development of molecular markers has opened up numerous possibilities for their application in plant breeding. PCR-based markers, including random amplified polymorphic DNA (RAPD), have been developed to effectively analyse of genetic polymorphism (Ko et al., 2002).

Five 10 mer arbitrary primers produced 42 DNA fragments with an average of 8.4 per primer. The size of the amplified products ranged from 350 to $20000 \mathrm{bp}$. Of the total 42 bands obtained, 41 were polymorphic. Percent of polymorphism ranged from 97.61 \% (RLZ1) to $100 \%$ (RLZ5, RLZ11, RLZ12, RLZ13). The most polymorphic primer was RLZ12, where 10 polymorphic amplification products were detected. Overleaf the lowest polymorphic primer was RLZ5 with 7 polymorphic products.

The frequencies of alleles and the values of DI, PI and PIC were calculated (Tab 3 ). All three features were calculated for all used RAPD primers by using individual frequencies of the fragments for each marker. The diversity index (DI) of RAPD markers ranged from 0.818 (RLZ5) to 0.862 (RLZ11) with an average of 0.843 . The lowest values of polymorphic information content were recorded for RLZ11 (0.859) and the lowest PIC values were detected for RLZ5 (0.814) with an average of 0.839 . Probability of identity was low ranged from 0.003 to 0.007 with an average of 0.007 that indicates the possibility to differentiate genetically close genotypes.

Persson et al. (2002) detected the amount and distribution of genetic variation within and between accessions of 9 landraces and 3 cultivars of cultivated rye from Northern Europe. They tested total of 100 primers, of which 15 were used. Of the 60 amplification products (bands) that were scored (an average of 3.9 bands/primers), 58 bands (97\%) found to be polymorphic. The average number of bands per primer for each accession was 2.75 the average percent of polymorphic loci was $68.9 \%$.

Previous studies reported that levels of polymorphism in rye detected by RAPD technique were $9-72 \%$ for various primers (Iqbal and Rayburn, 1994) and 45 $\%$ (Loarce et al., 1996). PIC values were determined 0.374 (Myśkow et al., 2001) 0.863 in rye (Petrovičová et al., 2014), in coffee 0.78 (Mishra et al., 2011) and in iris 0.178 (Azimi et al., 2012).

RAPD analysis is widely used for the study plant genetic polymorphism in wheat (Abd-El-Haleem et al., 2009; Cifci and Yagdy 2012) barley (Abdellaoui et al. 2010; Guasmi et al., 2012) triticale (Orlovskaya et al., 2012) and maize (Okumus, 2007; Mukharib et al., 2010). 
Table 3 Characteristics of RAPD markers used in this study

\begin{tabular}{lccccc}
\hline \hline $\begin{array}{l}\text { RAPD } \\
\text { Primers }\end{array}$ & $\begin{array}{c}\text { Number } \\
\text { of } \\
\text { fragments }\end{array}$ & $\begin{array}{c}\text { Polymorphism } \\
\mathbf{( \% )}\end{array}$ & DI & PIC & PI \\
RLZ1 & 8 & 97.61 & 0.855 & 0.849 & 0.003 \\
RLZ5 & 7 & 100 & 0.818 & 0.814 & 0.016 \\
RLZ11 & 8 & 100 & 0.862 & 0.859 & 0.003 \\
RLZ12 & 10 & 100 & 0.852 & 0.851 & 0.005 \\
RLZ13 & 9 & 100 & 0.830 & 0.823 & 0.007 \\
Average & 8.4 & 99.52 & 0.843 & 0.839 & 0.007 \\
\hline \hline
\end{tabular}

Legend: DI - diversity index; PI - probability of identity (PI); PIC - polymorphic information content

The dendrogram of genetic relationships among 38 rye cultivars based on RAPD primers is presented in Figure 1. The cluster tree analysis showed that the rye genotypes were divided into 3 main clusters

The group of RAPD primers were divided during the basic screening of 38 analysed cultivars. The first cluster was divided in two subclustres (1A and 1B). Subcluster 1A contains three genotypes of Czechoslovak origin. In the subgroup 1B were grouped 13 genotypes which were bred in Poland (53.8\%), Czechoslovakia (38.5\%), Czech Republic (7.7 \%). The second cluster was divided into two groups $(2 \mathrm{~A}$ and $2 \mathrm{~B})$. In cluster $2 \mathrm{~A}$ two rye genotypes were separated - Mnogokoloskaja (SUN) and Lovaszpatonai (HUN). Subcluster 2B included 4 genotypes of Union of Soviet Socialist Republics origin. The other rye varieties in the third cluster were divided into two subclusters (3A and 3B). Seven varieties of rye coming from Czechoslovakia and one genotype from Czech Republic formed subcluster 3A. Subcluster 3B contained eight rye genotypes originating from the Poland. We could not distinguish 2 genotypes, Wibro and Bosmo grouped in 3B subcluster, which can be caused due the same genetic background (Fig 1).

Persson et al. (2002), constructed dendrogram using UPGMA algorithm among the 12 rye accessions. The genetic distance value average among the accessions was 0.066 and the cophenetic correlation at the dendrogram was 0.907 . The fina dendrogram showed six clusters. The clusters I, IV, V and VI each include a single accession; one landrace from Sweden, one from Germany, one from Norway and one from Finland, respectively. In cluster II, two Swedish landraces were grouped together. The cluster III showed six accessions and it could be divided into two subclusters: the first one with three landraces from Sweden and the second one with three improved cultivars.

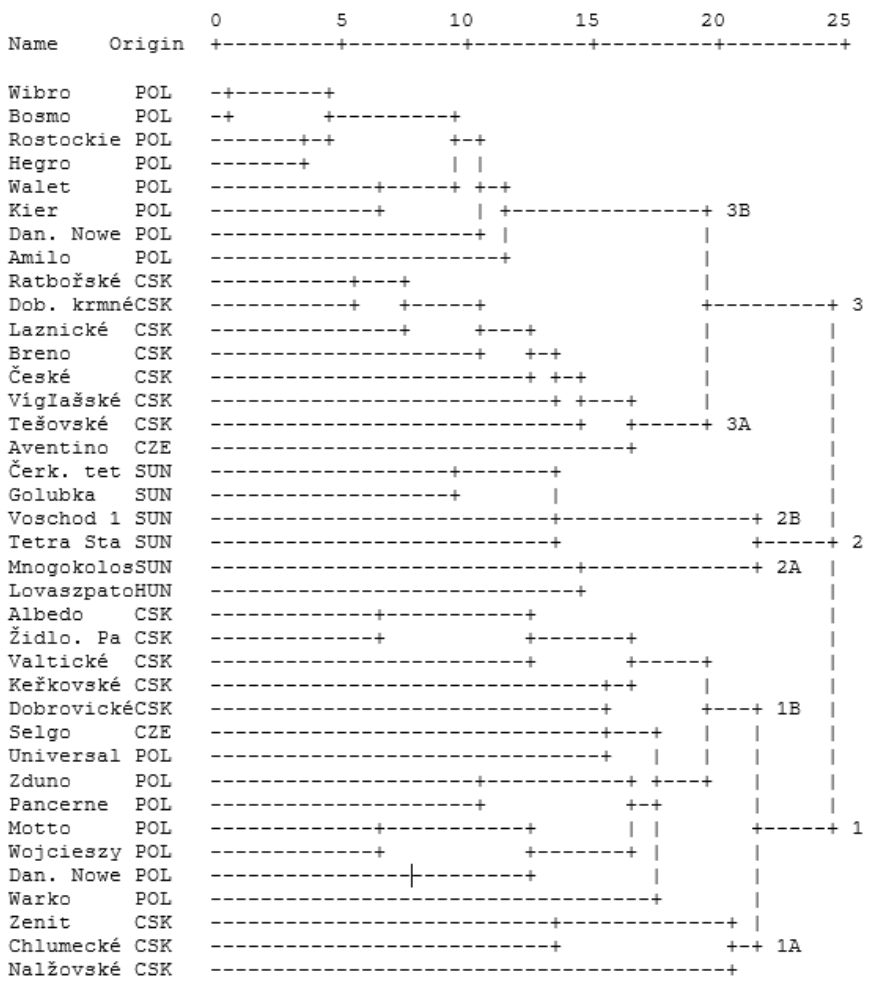

Figure 1 Dendrogram of 38 rye genotypes prepared based on 5 RAPD markers CSK - Czechoslovakia, CZ - Czech Republic, HU - Hungary, PL - Poland, SUN Union of Soviet Socialist Republics.

\section{CONCLUSION}

The objective of this study was to determine the genetic variation among 38 rye varieties using RAPD markers. Genetic polymorphism was characterized based on diversity index (DI), probability of identity (PI) and polymorphic information content (PIC). Values of the polymorphic information content value ranged from 0.814 to 0.859 with an average of 0.839 and diversity index value ranged from 0.818 to 0.862 with an average of 0.843 . The dendrogram was prepared based on the Jaccard's coefficient and divided in to three clusters. RAPD are commonly and extensively used tools for assessment of variability in crops. These marker systems are efficient due to their ease, rapidity and reliability, for analysis of molecular differentiation and for resolving taxonomic problems in plants. Our result showed appreciably high genetic diversity among the rye genotypes studied.

Acknowledgment: This study was supported by European Community under project No.26220220180: Building Research Centre „AgroBioTech“.

\section{REFERENCES}

ABDELlAOUI, R., KADRI, K., NACEUR, M. B., KAAB, L. B. B. 2010 Genetic diversity in some Tunisian barley landraces based on RAPD markers Pakistan Journal of Botany, 42(6), 3775-3782.

ABD-EL-HALEEM, S. H. M., REHAM, M. A., MOHAMED, S. M. S. 2009. Genetic Analysis and RAPD Polymorphism in Some Durum Wheat Genotypes. Global Journal of Biotechnology \& Biochemistry, 4 (1), 1-9.

ALTPETER, F., KONZUN, V. 2007. Rye. Biotechnology in Agriculture and Forestry, 59, 107-117.

AZIMI, M. H., SADEGHIAN, S. Y., RAZAVI, A. V., KHAZAEI, F., HAFASHJANI, F. A. 2012. Genetic variation of Iranian Iris species using morphological characteristics and RAPD markers. International Journal of AgriScience, 2(9), 875-889.

BAKHT, J., GHAFFAR, M., SHAFI, M., KHAN, S., LATIF, B. 2011 Determination of genetic diversity of different barley genotypes grown in Khyber Pakhtun Khwa province using RAPD markers. Pakistan Journal Botany, 43(5), 2491-2495.

BAKHT, J., JAMSHED, A., SHAFI, M. 2013. Genetic diversity and phylogenetic relationship among different peach genotypes through RAPD markers. Pakistan Journal Botany, 45(4), 1241-1245.

BIBI, S., KHAN, I. A., DAHOT, I. A., KHATRI, A., NAQVI, M. H., SIDDIQUI, M. A., YASMEEN, S., SEEMA, N. 2012. Estimation of genetic variability among elite wheat genotypes using random amplified polymorphic DNA (RAPD) analysis. Pakistan Journal Botany, 44(6), 2033-2040.

CARENA, M. J. 2009. Cereals. New York : Springer, 425 p. ISBN 978-0-38772294-8.

CIFCI, E. A., YAGDI, K. 2012. Study of genetic diversity in wheat (Triticum aestivum) varieties using Random Amplified Polymorphic DNA (RAPD) analysis. Turkish Journal of Field Crops, 17(1), 91-95.

DIVARET, I., MARGALE, E., THOMAS, G. 1999. RAPD markers on seed bulks efficiently assess the genetic diversity of a Brassica oleracea $\mathrm{L}$. collection. Theoretical and Applied Genetics, 98, 1029-1035. http://dx.doi.org/10.1007/s001220051164

GUASMI, F., ELFALlEH, W., HANNACHI, H., FERES, K., TOUIL, L., MARZOUGUI, N., TRIKI, T., FERCHICHI, A. 2012. The Use of ISSR and RAPDMarkers for Genetic Diversity among South Tunisian Barley. ISRN Agronomy, 2012, 1-10. http://dx.doi.org/10.5402/2012/952196

IQBAL, M. J., RAYBURN, A. L. 1994. Stability of RAPD markers for determining cultivar specific DNA profiles in rye (Secale cereale L.). Euphytica, 75(3), 215-220. http://dx.doi.org/10.1007/bf00025606

KO, J.M., DO, G.S., SUH, D.Y., SEO, B-B., SHIN, D-S. AND MOON, H-P. 2002. Identification of chromosomal organization of two rye genome- specific RAPD products useful as introgression markers in wheat. Genome, 45(1), 157 164. http://dx.doi.org/10.1139/g01-133

KORZUN, V., MALYSHEV, S., VOYLOKOV, A.V., BÖRNER, A. 2001. A genetic map of rye (Secale cereale L.) combining RFLP, isozyme, protein, microsatellite and gene loci. Theoretical and Applied Genetics, 102 (5), 709-717. http://dx.doi.org/10.1007/s001220051701

LOARCE, Y., GALLEGO, R., FERRER, E. 1996. A comparative analysis of genetic relationships between rye cultivars using RFLP and RAPD markers Euphytica, 88(2), 107-115. http://dx.doi.org/10.1007/bf00032441

MA, R., YLI-MATTILA, T., PULLI, S. 2004. Phylogenetic relationships among genotypes of worldwide collection of spring and winter ryes (Secale cereale L.) determined by RAPD-PCR markers. Hereditas, 140(3), 210-221. http://dx.doi.org/10.1111/j.1601-5223.2004.01844.x

MASOJC', P., MYS'KÓW, B., MILCZARSKI, P. 2001. Extending a RFLPbased genetic map of rye using random amplified polymorphic DNA (RAPD) and isozyme markers. Theoretical Applied Genetics, 102(8), 1273-1279. http://dx.doi.org/10.1007/s001220000512 
MATOS, M., PINTO-CARNIDE, O., BENITO, C. 2001. Phylogenetic relationships among Portuguese rye based on isozyme, RAPD and ISSR markers Hereditas, 134(3), 229-236. http://dx.doi.org/10.1111/j.1601-5223.2001.00229.x

MIRSHA, M. K., NISHANI, S., JAYARAMA, 2011. Genetic relationship among indigenous coffee species from India using RAPD, ISSR and SRAP markers. Biharean Biologist, 5(1), 17-24. http://dx.doi.org/10.2298/abs1103667m

MYŚKÓW, B, MASOJĆ, P., BANEK-TABOR, A., SZOŁKOWSKI, A. 2001. Genetic diversity of inbred rye lines evaluated by RAPD analysis. Journal of Appied Genetics, 42(1), 1-14. http://dx.doi.org/10.2478/v10129-011-0009-y

MUKHARIB, D. S., PATIL, V. C., BIRADAR, D. P., SALIMATH, P. M., CHIMMAD, V. P. 2010. Assessment of molecular diversity in selected maize inbreds. Karnataka Journal of Agricultural Sciences, 23(3), 409-412.

NILSSON, N. O., HALLDÉN, C., HANSEN, M., HJERDIN, A., SÄLL, T. 1997. Comparing the distribution of RAPD and RFLP markers in a high density linkage map of sugar beet. Genome, 40(5), 644-651. http://dx.doi.org/10.1139/g97-085

OKUMUS, A. 2007. Genetic Variation and Relationship Between Turkish Flint Maize Landraces by RAPD Markers. American Journal of Agricultural and Biological Sciences, 2(2), 49-53. http://dx.doi.org/10.3844/ajabssp.2007.49.53

ORLOVSKAYA, O. A., KOREN, L. V., KHOTYLEVA, L. V. 2012. Genetic Polymorphism Evaluation of Spring Triticale ( $\times$ Triticosecale Wittmack) Samples with Use of RAPD and ISSR Markers. Russian Journal of Genetics: Applied Research, 2(6), 508-512. http://dx.doi.org/10.1134/s207905971206010x

PAETKAU, D., CALVERT, W., STIRLING, I., STROBECK, C. 1995. Microsatellite analysis of population structure in Canadian polar bears. Mol Ecol., 4(3), 347-354. http://dx.doi.org/10.1111/j.1365-294x.1995.tb00227.x

PERSSON, K., BOTHMER, B. VON. 2002. Genetic diversity in landraces of rye (Secale cereale L.) from Northern part of Europe by using allozymes. Hereditas, 136(1), 29-38. http://dx.doi.org/10.1034/j.1601-5223.2002.1360105.x

PETROVIČOVÁ, L., BALÁŽOVÁ, Ž., GÁLOVÁ, Z., WÓJCIK-JAGŁA, M., RAPACZ M. 2014. RAPD Analysis of the Genetic Polymorphism in the Collection of Rye Cultivars. International Journal of Biological, Veterinary, Agricultural and Food Engineering, 8(7), 631-635.

PETROVIČOVÁ, L., GÁlOVÅ, Z., BALÁŽOVÁ, Ž., VIVODÍK, M., WOJCIK-JAGŁA, M., RAPACZ M. 2014. Genetic diversity of czechoslovak origin rye cultivars detected by RAPD markers. CECE $2014\left(11^{\text {th }}\right.$ International Interdisciplinary Meeting on Bioanalysis) Brno : Institute of Analytical Chemistry, 353-356.

SALEH, B. 2012. Biochemical and Genetic Variation of some Syrian Wheat Varieties using NIR, RAPD and AFLPs Techniques. Journal of Plant Biology Research, 1(1), 1-11.

WEBER, J. L. 1990. Informativeness of human (dC-dA)n x (dG-dT)n polymorphism. Genomics 7( 4), 524-530

http://dx.doi.org/10.1016/0888-7543(90)90195-z

WEIR, B. S. 1990. Genetic data analysis. Sinauer Associated, Sunderland: Massachusetts, 1990, pp. 445.

WILLIAMS, J. G., KUBELIK, A. R., LIVAK, K. J., RAFALSKI, J. A., TINGEY, S. V. 1990. DNA polymorphisms amplified by arbitrary primers are useful as genetic markers. Nucleic Acids Research, 18 (22), 6531-6535. http://dx.doi.org/10.1093/nar/18.22.6531

YANG, X., QUIROS, C. F. 1995. Construction of a genetic linkage map in celery using DNA-based markers. Genome, 38(1), 36-44. http://dx.doi.org/10.1139/g95005 